\title{
PRE-GLACIAL BEACHES OF BRIDLINGTON AND S. OF IRELAND.
}

Sir,-In the July number of the Grological Magazine, Mr. A. R. Hunt, in a paper on "The Geological Physics of the Shallow Seas," contrasts the pre-Glacial beaches of Bridlington and of the South of Ireland, and says, "But in the Irish beaches . . . . we have, much further south, the rock-platform itself ice-scored, affording no accommodation for hippopotami." These ice-scorings, however, occur only where a deposit of boulder-clay lies immediately on the platform, and, whatever may be the direction of the coast, the direction of the strixe on the platform remains parallel to those occurring under boulder-clay on higher ground inland. Nothing was seen to suggest that strim occurred between the beach-platform and the beach-gravel, or that the beach-gravel had ever been disturbed by ice before the accumulation of the lower 'head.' The strix, therefore, are not of the same age as the beach, and do not indicate the prevalence of glacial conditions during the formation of the beach. As at Bridlington, the beach "need not represent so cold a climate as that which followed." In this point, as in so many others, the South of 'Ireland pre-Glacial beach agrees with that of Bridlington. Consequently there is no reason from considerations of climate why the Irish cave fauna should not be found in the Irish coast-sections in a position similar to that of the mammalian remains in the Bridlington section. Nor do the "shells with a southern range on Devonshire beaches of the same levels" afford an obstacle to the correlation of these with the Irish beaches. The erratic pebbles found in the Irish beaches are not against this correlation, since erratics are also found in the Devonshire beaches.
GLencoe.
July $22 n d, 1905$.
H. Brantwood MUfr.

\section{MUSEUM BOLTENIANUM, PART 2, 1798.}

Sir, - The rarity of part 2 of this work, which relates to Mollusca, is well-known to students. In response to a number of enquiries it is proposed to reproduce a few copies, by photographic facsimile, from the Crosse copy now in the British Museum (Natural History).

The large number of pages (204) must render this a somewhat costly task, and we should be glad to know if any of your readers would care for a copy to be reserved for them at the price of $£ 2$ per copy.

The work would be done, under our supervision, by Mr. F. W. Reader.

The issue will be limited, numbered, and signed, and could be prepared for distribution during the Autumn.

It must be clearly understood that unless sufficient subsoribers are forthcoming, no issue can be made.

Any intending subscriber should address Mr. E. R. Sykes, 3, Grays Inn Place, Grays Inn, London.

June, 1905.

E. R. SYKes.

C. Davies Sherborn. 